IKONOMIKA: Jurnal Ekonomi dan Bisnis Islam

Volume 5, No - I (2020)

ISSN : 2527-3434 (PRINT) - ISSN: 2527-5I43 (ONLINE)

Page : IOI - II6

\title{
Research And Development Of Organic Fertilizer From Banana Peels: Halalan Tayyiban Perspective
}

\author{
Md Akmal Salihin ${ }^{1}$, Ak Md Nur Ajrun'azhim², Md Hirzi ${ }^{3}$, HajahJanatul Ain ${ }^{4}$, Khairul \\ Atiqah $\mathrm{And}^{5}$, Haziqah Najwa ${ }^{6}$, Pengiran Norkhairiah ${ }^{7}$, Mohd.Shahril Ahmad
}

\author{
Islamic University of Sultan Sharif Ali Brunei Darusaalam ${ }^{1,2,3,4,5,6,6}$ \\ Univesiti Utara Malaysia ${ }^{8}$
}

\author{
akmalibnzakir@gmail.com ${ }^{1}$,ajrun.219@,gmail.com²,yin.jamil@gmail.com", \\ atiqaharsyad@gmail.com ${ }^{5}$,ziqahnajwa.07@,gmail.com6 \\ norkhairiah.hashim@,unissa.edu.bn' ${ }^{7}$, shahril@uum.edu.my ${ }^{8}$,
}

\begin{abstract}
In modern agriculture, most of the biochemicals and inorganic fertilizer had been used for the plantation on the worldwide scale. Whilst, the issue of food waste had created concern for the global community because of its potential for pollution. In Brunei Darussalam, food waste has the highest percentage followed by paper and plastic. According to the Scientia Bruneiana, vol.17, no.2, according to the Department of Environment, Parks, and Recreations, 400 - 500 tonnes of waste goes to Sg. Paku landfill in Tutong District each day. This issue was raised by the people that prioritized the application of the Macro Organic Local which is the organic fertilizer derived from rainwater and food waste. They emphasize the concept of zero-waste and go-green to manage the problems of the polluted environment. Therefore, 'Potilizer' production that is based on the organic sources mainly from banana peels is to solve the problems of food waste and raise awareness to the community to reduce waste. 'Potilizer' aims to reach out to the farmers, entrepreneurs, and individuals to fully utilize organic waste and to be confident in its usage. The methodology used is by conducting some experiments on each type of plant-based on the research study from the existing information with regard to farming. The use of data collection is from the books, the internet, by interviewing the farmers and conducting the survey about natural fertilizer. The novelty of this product is by the application of the conservation concept and it will present as the first organic fertilizer in Brunei Darussalam to be commercialized at a very affordable price and good quality. 'Potilizer' has the opportunity to penetrate the market as it can benefit the farmers, entrepreneurs, agricultural school institutions, as well as for the house-gardening purposes to assist them in this field.
\end{abstract} Keyword: Potilizer, Organic Fertilizer, Banana Peels, Plant Growth, Food Waste

Received: August 26,2020 - Revised: August 26,2020 - Accepted: August 3I,2020 Occupuation : Islamic University of Sultan Sharif Ali Brunei Darusaalam E-mail : ajrun.219@gmail.com ${ }^{1}$, yin.jamil@gmail.com ${ }^{3}$, ziqahnajwa.07@gmail.com ${ }^{4}$, atiqaharsyad@gmail.com ${ }^{5}$, akmalibnzakir@,gmail.com ${ }^{6}$, shahril@,uum.edu.my ${ }^{7}$, norkhairiah.hashim@,unissa.edu.bn ${ }^{8}$ 


\section{A. INTRODUCTION}

In modern agriculture, most of the biochemicals and inorganic fertilizer had been used for the plantation on the worldwide scale. Whilst, the issue of food waste had created concern for the global community because of its potential for pollution.

Above is his Majesty the Sultan of Brunei Darussalam declamation on the potentiality of the youth in developing the agricultural area with their capabilities in using various ways of method that would apprehend the international level. The speech was during the I4th Youth Day Celebration in Brunei which was held on the 3rd August 2019 at the Plenary Hall, International Convention Centre.

As a reference to His Majesty's speech, here we put the initiative by figuring out the solution by releasing the ideas on the formation of organic fertilizer. The words "organic" means that the product is only minimally processed, and the nutrients remain in their natural forms, rather than being extracted and refined.

Organic fertilizer is usually made from plant or animal waste or powdered minerals. They are usually sold as "soil conditioners" rather than as fertilizer because the nutrient ratios are difficult to guarantee. Organic fertilizers may be processed in a factory but in our case, it is processed in our house. Our objective in making this product is because we want to help Brunei achieve its vision that is zero-waste, go-green, and recycle. We also want to make an innovation in agricultural sectors to help start-up farmers.

\section{B. THEORETICAL}

\section{Problem Statement}

The inspiration for this product is from our concerns on certain problems happening in Brunei which should be taken into account. One of the main factors is, the awareness of go-green is still in a crucial stage and without active actions, it would threaten the environment. As an evident, In Brunei Darussalam, food waste has the highest percentage followed by paper and plastic. According to the Scientia Bruneiana, vol.17, no.2, according to the Department of Environment, Parks, and Recreations, 400 - 500 tonnes of waste goes to Sg. Paku landfill in Tutong District each day (Arnarson, 2019). This issue was raised by the people that prioritized the application of the Macro Organic Local which is the organic fertilizer derived from rainwater and food waste. Apart from that, this product also aims for innovation by including Halal elements in which the awareness of this matter is usually limited to food. In agriculture, the elements of Halal also important as it related to food production, especially, and by this innovation, it would remove the hesitation in using fertilizer. 
According to (Zainal abidin Mohamed \& Mad Nasir Shamsudin, 20I5) by associating the Halal principles and production, it would support sustainable agriculture. By means, from the initial stage of agriculture up until the cultivation stages, the Halal elements are needed to be practiced in order to achieve food safety, environmentally friendly, fair trade, and animal welfare. Therefore, a variety of initiatives are being done in order to achieve Brunei's vision through some innovation in some areas, especially the agriculture sector.

\section{Product Development}

The establishment of Potilizer was started from doing some research and gathering all the important information. The survey was taking around five days which encompasses; buying some different banana fruits, sunflower seeds, and the two types of vegetables which are Pak Choy and Rossella. After completing all the items needed, we conducted our own home-based experiment on the seeds and applied the Potilizer on the plants. Here, we could figure out the potentials of Potilizer as an organic fertilizer.

Based on the main element of Potilizer which is the banana, despite its differences in name, creation, shape, and size, the element inside the Potilizer are similar but the darker outer part of the banana, so the greater number of glucose will be gathered in the banana which also benefited to the plants. According to experts, for example, the function of glucose for the plants is to feed the plants which often by assisting them to grow, forming flowers and developing fruits. The presence of glucose in a plant is from the result of photosynthesis. So here, if the plant is deficient in glucose, our product could be the main supporter as it is richest with this element. Meanwhile, the production processes of Potilizer were approximately 4-5 days including the soaking process which is the most important part of its production. Once it reaches the 5th day, the banana must be filtered to separate the banana peel from the water and simultaneously avoid it from polluting the environment as the smells could attract uninvited insects. The first trial on the use of Potilizer was quite ineffective and the factor could be from the way we applied it to the plants and also the error occurred during the plantation processes.

The trial was done on sunflower seeds and there were also some new elements added which are potatoes and honey. The new elements are chosen to be the additional ingredients on Potilizer because of its assistance towards the healthy growth of the plants. The honey, for example, acts as an aid in flowering and fruiting the plants as well as making the taste more flavourful. While the potatoes also can be the best source of nourishment for plants which is through its starch and the peels by releasing the plant nutrients in the soil. Unfortunately, we have forgotten the honey could attract the ants to the plants by ignoring suitable places. The insect could endanger the plants especially 
the newly planted plants and spraying the insect repellent would be not the first solution.(Zara Ingilizian, 2019)

Banana peels is enriching the water with its nutrients. There will be instruction applied or 'direction of uses' for the 'Potilizer' usage as a way to achieve the best result. The guide is starting from filling the pot or any recycle goods (preferable) from the choice of the users with the soils for approximately until half $(\mathrm{I} / 2)$ of the pot or the recycle goods were filled. Then, the soil must be dug for about one over four (I/4) of a teaspoon and put half $(\mathrm{I} / 2)$ of the seed's body into the soil. After that, the seed has to be covered with the remaining dig up soil from before. It must be noted that after this process has finished, exposing the potted plants to the direct sunlight must be avoided in order for the germination process to occur successfully. Pour approximately IOmililitre $(\mathrm{ml})$ of the 'Potilizer' onto the plants until it grows. After the plants have shown the signs of the growth or there are leaves sticking out from the soil, then direct sunlight is needed for the plants to get the particular nutrients from the sunlight.

The reason for choosing the banana peels as the main elements for 'Potilizer' is because the banana peels contain macronutrients for fertilizer needed by the plants which are Nitrogen, Phosphorus, Potassium, Calcium, Sulfur, and Magnesium. Whilst the micronutrients from the banana peels are Iron, Manganese, Boron, Zinc, Copper, and Molybdenum which can promote the growth of garden plants from seed germination to blooms and fruits.

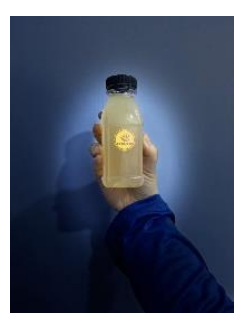

\section{Materials}

The used materials were the banana peels from the local shops particularly in Tutong and Brunei and Muara District, Brunei Darussalam. Whilst, some of the sources of banana peels originated from the individual's own garden. The ripe banana peels that had many black spots on it are the most preferable choices for this product as it contains various nutrients during these stages.

Distilled water is chosen for the fermentation process of the banana peels under the room temperature. The utensils used for this experiment are recycled things corresponding with the concept of the product which is environmental-Friendly. The origin of making this product was when one of the team members named Najwa 
whereby she was doing her academic writing regarding organic fertilizer. She can see that with the help of more people, the fertilizer can really help the country to solve the problem. Through many discussions among her friends, they decide to make a group to join the faculty competition where the word 'Potilizer' is made.

Potilizer is a word that combines from the word pot and fertilizer. We use the word 'pot' because our product can be used, especially for the houseplant. We do many trial and error because we really want these things to work out. We won 2 nd place in the competition and that's where we were elected to be UNISSA's representatives to compete in the Virtual Innovation Competition 2020 (VIC) that was held in UITM Kelantan. (Haifa Group, 2020)

We have achieved platinum and gold awards thanks to the guidance from our lecturer Dr.MohdShahril and Dr.Pengiran Dr Norkhairiah who really help us a lot with our product. All the data we collected are through an online survey with the aim to ease in reaching people and avoiding time consuming and money, as well as maintaining the social distancing for the current pandemic disease. 'Potilizer' production that is based on the organic sources mainly from banana peels is to solve the problems of food waste and raise awareness to the community to reduce waste. The item that we use to make fertilizer is banana peel and all of it comes from the people who only need to take the banana inside it such as 'cucur pisang' seller. We also use our family member that eats bananas then the peel is put in a plastic that we prepare for collection. The potilizer is good because it has many nutrients that were needed for a plant such as NPK.

The second trial of the production was successful and only $100 \mathrm{ml}$ of Potilizer is being used in the plant. This time, the ingredients inside the Potilizer are only banana water and potatoes. The supplication was applied to the potted flower which is rose and the water is proven to be successful as a fertilizer because it has the potentiality to make the plants survive for several weeks by following full instruction of its usage. However, excess usage should be avoided whereas it is enough to ensure the plants got the health supplication through the fertilizer. Basically, the blossoming of Potilizer is started from joining the Halal Product Innovation Competition organized by HalalanThayyiban

Research Centre, University Islam Sultan Sharif Ali, Brunei Darussalam. The competition was held on I6 th May 2020 via zoom and there were four groups joining the event and only two groups were eligible for the international competition in Malaysia. During the competition, our group won 2 nd place with the Potilizer as our product. During the Virtual Innovation Competition that was organized by the University Technology Mara Kelantan, Malaysia, our group received Platinum and Gold Medal awards in the Social Science (B) category. 


\section{Product Resources}

In general, it is the group initiatives in producing this Potilizer whereas the tasks were divided equally among the members by the head of this group. In terms of capital, at first, it was done voluntarily as we got a very limited time; simultaneously we should maintain the social distance due to pandemic diseases. While, in terms of farming utensils, banana peel, and the packaging for prototype, all of these items are majority from the recycling resources which are in line with our objective in targeting the zerowaste, go-green and recycle.

Initial stages until the final product. The initial stages of 'Potilizer' are by obtaining the product concept of the environmentally friendly and the organic-based product from academic research. From that, the product concept began developing into a prototype. The main elements in the 'Potilizer' are banana peels and distilled water use for soaking the banana peels. The ripe banana peels consist of strong and impactful use of its nutrients for fertilizer purposes rather than fresh banana peels. The number of banana peels used is determined by the amount of volume of the liquid of the product.

The longer the fermentation process occurs, the better are the product performance for its users. The usual measured time of the fermentation of the banana peel for the fertilizer purpose is estimated for about a month to extract the nutrients from the banana peel.

\section{METHODOLOGY}

The method used in making the Potilizer is through academic research and field experiments. Both research methods are aiming for a sufficient and effective result of this product by gathering all the important information.

\section{Academic research}

The academic research is conducted with the aims to get an authentic information in regards to the types of banana, additional elements, packaging, and the process of fermentation. The purpose of emphasizing on specific points is to sustain the objective of this product which are; zero-waste, go-green, and recycle (H. F Hassan, 20I8).

I. Banana Peels

The first attempt of this research is focusing on the different types of banana. Based on the research, the main.

Element of Potilizer which is the banana, despite its differences in name, creation, shape, and size, the element inside the Potilizer are similar but the darker outer part of the banana, so the greater number of glucose will be gathered in the banana which also benefited to the plants. According to experts, for example, the function of glucose for the plants is to feed the plants whilst assisting them to grow, forming flowers and 
developing fruits. The presence of glucose in a plant is from the result of photosynthesis. So here, if the plant is deficient in glucose, our product could be the main supporter as it is richest with this element because the total content of glucose in a ripe banana could reach more than $16 \%$ of the fresh banana. [I]

\section{Product Packaging}

For the packaging of our product, in order to reduce waste, we are reusing the bottles that can keep and store 'Potilizer' safely. Reusing material to produce Potilizer is a brilliant way to reduce waste especially the use of plastic bottles as the production of plastic bottles includes a wide coverage of pollution as well as to decompose that might take several years. The creation of reusing water bottles on the other hand may help to create awareness on what the community can do in addition to recycling the use of recycling bottles. [2]

\section{Process of Fermentation}

In regard to this, the research was done in two ways which are theoretically and practically. This part was the most crucial part in which every important step should be followed as it has correlations on the efficiency of this product. Therefore, the academic research on this matter should be done thoroughly to lessen the error that might happen during the practical process as it encompasses from the initial stages of the process until the end product.

\section{Field Experiment}

The experiment was started by cutting out three pieces of ripe banana peels into 2 centimetres and soaked it with the distilled water. This fermentation process continues for about 4 to 5 days. When the fermentation has reached the preferable minimum time for at least a month, the result would show that the banana peel has observed almost one-half $(\mathrm{I} / 2)$ volume of the liquid showing that this stage resulting in the banana peels had enriched the water with its nutrients. The plantation stage starts from filling the pot or any recycle goods (preferable) from the choice of the users with the soils for approximately until one-half $(\mathrm{I} / 2)$ of the dug for about one quarter (I/4) of a teaspoon and put one-half $(\mathrm{I} / 2)$ of the seed's body into the soil. After that, the eedhas to be covered with the remaining dig up soil from before. It must be noted that after this process has finished, exposing the potted plants to the direct sunlightmust be avoided in order for the germination process to occur successfully. Pour approximately IOmililitre (ml) of the 'Potilizer' onto the plants until it grows. After the plants have shown the signs of the growth or there are leaves sticking out from the soil, then direct sunlight is needed for the plants to get the particular nutrients from the sunlight.

Table I. Mineral Composition of Banana Peel (mg/IO0g) ref 3 


\begin{tabular}{|l|l|l|}
\hline MINERAL & CONCENTRATIONS & RDA (mg/IO0g) \\
\hline Phosphorus & 2II.30 $\pm \mathrm{I} .24$ & 270 \\
\hline Magnesium & $44.50 \pm 0.08$ & $\mathrm{I} 70$ \\
\hline Sodium & II $5.10 \pm 0.26$ & 70 \\
\hline Iron & $47.00 \pm \mathrm{I} .26$ & 35 \\
\hline Calcium & $59.10 \pm 0.85$ & 260 \\
\hline Copper & $0.5 \mathrm{I} \pm 0.02$ & 0.9 \\
\hline Potassium & & \\
\hline Manganese & $4.39 \pm 0.15$ & 220 \\
\hline Zinc & $0.702 \pm 0.09$ & 3 \\
\hline
\end{tabular}

Values are mean \pm standard deviation $(n=5)$. ${ }^{\star}$ Source: (Ramirez-Orduna et al. 2005). (H. F Hassan, 2018)

\begin{tabular}{|l|l|}
\hline Nutrient & Functions \\
\hline Nitrogen (N) & Synthesis of proteins (growth and yield). \\
\hline Phosphorus (P) & $\begin{array}{l}\text { Cellular division and formation of } \\
\text { energetic structures. }\end{array}$ \\
\hline Potassium $(\mathrm{K})$ & $\begin{array}{l}\text { Transport of sugars, stomata control, } \\
\text { cofactor of many }\end{array}$ \\
\hline enzymes & Reducessusceptibility to plant diseases \\
\hline Calcium $(\mathrm{Ca})$ & $\begin{array}{l}\text { A major building block in cell walls,and } \\
\text { reducessusceptibility todiseases. }\end{array}$ \\
\hline
\end{tabular}




\begin{tabular}{|l|l|}
\hline Sulfur $(\mathrm{S})$ & $\begin{array}{l}\text { Synthesis of essential amino acids cystin } \\
\text { and methionine. }\end{array}$ \\
\hline Magnesium $(\mathrm{Mg})$ & $\begin{array}{l}\text { The central part of the chlorophyll } \\
\text { molecule }\end{array}$ \\
\hline Iron $(\mathrm{Fe})$ & Chlorophyll synthesis. \\
\hline Manganese $(\mathrm{Mn})$ & Necessary in the photosynthesis process \\
\hline Boron $(\mathrm{B})$ & $\begin{array}{l}\text { Formation of the cell walls. Germination } \\
\text { and elongation ofpollen tubes. }\end{array}$ \\
\hline Zinc $(\mathrm{Zn})$ & Auxins synthesis \\
\hline Copper $(\mathrm{Cu})$ & $\begin{array}{l}\text { Influences in the metabolism of nitrogen } \\
\text { and carbohydrates }\end{array}$ \\
\hline Molybdenum $(\mathrm{Mo})$ & $\begin{array}{l}\text { Component of nitrate-reductase and } \\
\text { nitrogenase enzymes. }\end{array}$ \\
\hline & \\
\hline
\end{tabular}

Table 2. Main function of the plant nutrients. (Haifa Group, 2020)

The observation is conducted through experiencing the plantation processes and this enables the observant enhancing their understanding of the growth of the plants despite lacking in terms of the laboratory experiment. Conducting a practical experiment and collecting data from the authentic references is the methodology of this production which aims for a valid result of the product. Based on the test result, this product is wellproven of its effectiveness and suitable for any type of plant. As evidence, this product has been tested on sunflower seeds on the two different pots.

Along the process, the Ist pot of the sunflower seeds used the banana peel liquid extract. Whilst, the 2 nd pot of the sunflower seeds used the crushed banana peel along with the banana peel water and it had been added some honey extract. After several hours of the plantation process, the 2 nd pot of the sunflower seeds was approached by the ants. On the 2 nd day, the 2 nd pot of the sunflower seeds was still in a wet condition while the other pot was drained as the water had already been observed by the soil.

Thus, there are some precautions that should be taken especially in placing the plants in certain places and storing the 'Potilizer' to avoid changes in the quality of our product. For further result in witnessing the efficiency of the product, the practical study 
still needed much time to observe the growth of the plants as well as the assistance for the laboratory equipment and data collection. Product improvement / modification/ evolution One of the alternatives in engaging with product development is to add other compatible organic elements to the product in order to enhance the efficiency of the product usage.

The possible choices at the moment are to add other fruit peels such as the pomegranate peels, orange peels, sweet lime peels, and others. These choices are based on academic research presented with the data and test results. However, these are subjected to changes along the process of modifying this product. 'Potilizer' will also undergo modification in terms of its product structures or physical characteristics as the product will increase in size as well as in its volume. The purpose of this modification is so that the users can use sufficient amounts of organic fertilizer from 'Potilizer' for the growth of their plants.

This is also to cater to the needs of the target customer which are the Small and Medium Enterprises (SMEs), relevant agencies such as Darussalam Enterprises, and the local farmers in Brunei Darussalam. Product Design and Prototype I. Name Initially, the product name 'Potilizer' was inspired by two different words which are Pot and Fertilizer. In the process of research, it has been stated that the use of banana peel as a fertilizer is suitable for the potted plants. Fertilizer plays an important role in enriching the plant with nutrients which will then help to bring benefit to consumers for their plantation.(Sublime Garden Design.(n.d.), n.d.)

Thus, the name of 'Potilizer' was created from that as the main objectives of our product to cater the problems of food waste and to bring the benefit of banana peel to pot plants. 2. Logo As for the design of the logo, the yellow colour and the picture of banana define the main elements of our fertilizer which is banana peel. While the black background considers the absence of color but expressing the feelings of elegance, substance and power, it showed the superiority of 'Potilizer' in solving plantation problems especially on the soil and enhancing the wellness and growth of plants. As for the circle logo shape of 'Potilizer' is symbolized with security, continuity, and protection shows the benefit of the use of 'Potilizer' in the agriculture sector as it would still be maintained in the future and its production will be improvised in which there is a possibility of making it as soil bygone through some processes.

For the packaging of our product, in order to reduce waste, we are using reused bottles that can keep and store 'Potilizer' safely. Reusing material to produce Potilizer is a brilliant way to reduce waste especially the use of plastic bottles as the production of plastic bottles includes a wide coverage of pollution as well as to decompose it might take several years. The creation of reusing water bottles on the other hand may help to 
create awareness on what the community can do in addition to recycling the use of recycling bottles. 4. Costs of production As for the elements of 'Potilizer' are a very low budget and affordable price for the customers. The estimated price is ranged from BND $\$ 3$ to BND\$5 depending on the quantity of the 'Potilizer' that the customer purchased.

\section{Market Analysis}

Strengths

Marketers get access to new markets and gain an advantage over competitors that are not focusing on "greenness". 2. Marketers can charge a premium on products that are seen as more eco-responsible. 3. Organizations that adopt green marketing are perceived to be more socially responsible. 4. Green marketing builds brand equity and wins brand loyalty among customers. 5. Fully derived from plant origins which is safe for the long term and does not create any residue and zero pollution. 6. Indirectly protecting the environment as we are helping to lessen the food waste by reusing the banana peels as well as our environmentally friendly packaging.

\section{Weakness}

Most customers choose to satisfy their personal needs before caring for the environment. 2. Overemphasizing greenness rather than customer needs can prove devastating for a product. 3. Many customers keep away from products labelled "Green" because they see such labelling as a marketing gimmick, and they may lose trust in an organization that suddenly claims to be green. 4. We cannot cater to mass production for those who wish to buy in bulk at the moment, as we only have limited resources.

\section{Opportunities}

Marketing to segments that are becoming more environmentally aware and concerned. These consumers are demanding products that conform to these new attitudes. 2. Organizations perceive green marketing to be a competitive advantage, relative to the competitors. Firms, therefore, strive to improve upon their societal awareness. This complements the increase in consumers' socially conscious behavior and will, therefore, give them an advantage over competitors who do not address these issues. 3. It can spark interest in those who wish to start their farming journey by using their very own local product which is Potilizer.

\section{Threats}

Uncertainty as to the environmental impact of present activities, including that is perceived to be less environmentally harmful. 2. Uncertainty as to which green marketing activities are acceptable from a government perspective. 3 . The possibility of a backlash from consumers or government based on existing green marketing claims, 
threats one and two above may cause backlash to arise. 4. Organic fertilizer from foreign products, as their fertilizers are widely being used before the locals try to penetrate the market.

\section{Market Impact}

Potilizer is aiming to be the global process of agricultural production system environmentally friendly, healthier, and more sustainable that can give an impact on governments, businesses, consumers, and other stakeholders. However, it is becoming increasingly urgent. The current problem with the food system, from production to consumption and waste treatment, contributes (20-30\%) to global greenhouse gas emissions and has affected the scarcity of the resources.

The first step in making the agri-food sector more sustainable is a clear and comprehensive research and analysis of the impact. Accurate and clear information provides the essential basis for this. However, quantifying the impact of agricultural food products can be rather complex. On the other hand, we are trying to give a positive impact on the halal industry and giving an excellent example of halal refers to the manner of producing goods and services and in the manner approved by Islamic law or Syariah.

The halal food industry is thus crucial for Muslims all over the world as it serves to ensure that the food items that they consume daily are Syariah compliant. It is an industry that is set for tremendous growth. With a global Muslim population of I.8 billion, the market for halal food is estimated at US\$547 billion a year (Dierks, 20I I) Political.

To provide a positive impact from the Potilizer, we need to fulfil the local demand for fertilizers at affordable prices, the Government is now providing help and full support for all local businesses on the production and import of agricultural products including fertilizers. The government can provide suppliers from the local businesses to get us banana peel, eggshell, and potato peel. Tax relaxation has also been offered by the Government, giving export benefits to suppliers of capital goods new projects involving fertilizer. (Author, 2018).

By improving the agricultural sector in Brunei, can reduce unemployment rates by providing more jobs and this can directly improve the infrastructure of the country and some other factors such as reducing the level of poverty and crime. Tax relaxation has been offered in order to attract new buyers and to reduce the dependence on imported fertilizers by enhancing the local production capacity. The Government is providing a subsidy on the production and import of fertilizers. Furthermore, drastic improvement 
of the agricultural sector can definitely attract foreign direct investment (FDI) and will surely help the development of Brunei's economy.

Social

As we all know, the traditional process of making fertilizer can affect the environment because of the improper handling of the waste. Due to this, many diseases like asthma, kidney diseases, hepatitis, etc are caused. This is where Potilizer act to help reduce problems.

Potilizer is using eco - friendly packaging, the clearest benefit of eco-friendly packaging is in relation to protecting our environment. Our packaging is usually made from biodegradable, recycled material which reduces the waste of natural resources for production. In addition, the manufacturing process tends to be more efficient, further reducing precious resources and minimizing the negative impact businesses have on the environment. Technological In order to meet the expectation of fertilizers in the country, a strong technological advancement base is required in the planning and development of specific engineering and expertise in producing and improving the research and development $(\mathrm{R} \& \mathrm{D})$ of Potilizer in aims to achieve the maximum potential the agricultural sector in halal industry needs.

\section{RESULTS AND DISCUSSIONS}

This product has been tested on sunflower seeds on the two different pots. Along the process, the Ist pot of the sunflower seeds used the banana peel liquid extract. Whilst, the 2nd pot of the sunflower seeds used the crushed banana peel along with the banana peel water and it had been added some honey extract. After several hours of the plantation process, the 2 nd pot of the sunflower seeds was approached by the ants. On the 2 nd day, the 2 nd pot of the sunflower seeds was still in a wet condition while the other pot was drained as the water had already been observed by the soil. Thus, there are some precautions that should be taken especially in placing the plants in certain places and storing the 'Potilizer' to avoid changes in its quality for usage. For further result in witnessing the efficiency of the product, the practical study still needed much time to observe the growth of the plants as well as the assistance from the laboratory equipment and data collection.

\section{E. CONCLUSION}

In conclusion, a study in the United Kingdom found that, on average, organic farming results in 20\% higher levels of soil carbon than conventional farming. A 20 I I report published by the United Nations' Food and Agriculture Organization reported significantly higher soil carbon content in 480 organically managed farms across North 
Research And Development Of Organic Fertilizer From Banana Peels: Halalan Tayyiban Perspective Ak Md Nur Ajrun'azhim ${ }^{1}$, Md Hirzi ${ }^{2}$. HajahJanatul Ain ${ }^{3}$, Haziqah Najwa ${ }^{4}$ Khairul Atiqah And ${ }^{5}$, Md Akmal Salihin ${ }^{6}$, Mohd.Shahril Ahmad ${ }^{7}$, Pengiran Norkhairiah ${ }^{8}$

America, Europe, Asia, and Australia. Potilizer also tends to release any chemicals into the soil that contain nutrients helpful to the soil and can be easily biodegradable. When it comes to carbon footprints, organic is vastly better for the environment than conventional. This research proves that Potilizer can create a positive impact in terms of its effect on sustaining and protecting the environment. 
IKONOMIKA

Volume 5, No I (2020)

\section{REFERENCES}

Arnarson, A. (2019). Healthline. Retrieved from Bananas IOI: Nutrition Facts and Health Benefits: Https://Www.Healthline.Com/Nutrition/Foods/Bananas. Author, G. (2018). Looka. Retrieved from Looka Web Site:

Https://Looka.Com/Blog/Logo-Shapess-Meanings/Federal Board of Revenue (2009) [Online] Retrieved from Http://Www.Cbr.Gov.Pk/News/Default.Asp.

Dierks. (20I I). Market Watch 2010 - The Food Industry. Malaysian-German Chamber of Commerce \& Industry.

H. F Hassan, U. F. (20I8). ARC Journal. Retrieved from AR C Journal Web Site:

Https://WwW.Arcjournals.Org/Pdfs/Ijarcs/v5- I5/3.Pdf.

Haifa Group. (2020). Haifa Group. Retrieved from Haifa Group Website:

Https://Www.Haifa-Group.Com/Banana-Fertilizer/Crop-Guide-Banana-

Fertilizer.

Sublime Garden Design.(n.d.). (n.d.). No Title. Retrieved from

Https://Sublimegardendesign.Com/about-Sublime-Garden-Design-LandscapeArchitecture/f Aqs/.

Zainal abidin Mohamed \& Mad Nasir Shamsudin. (2015). Can Halal Be Sustainable?

Study on Malaysian Consumer's Perspective. Journal of Food Products Marketing, Pg 654 .

Zara Ingilizian, S. . (2019). We Forum. Retrieved from We Forum:

Https://Www. Weforum.Org/Agenda/2019/07/Reusable-Plastic-Packaging/. 
Research And Development Of Organic Fertilizer From Banana Peels: Halalan Tayyiban Perspective Ak Md Nur Ajrun'azhim ${ }^{1}$, Md Hirzi ${ }^{2}$, HajahJanatul Ain ${ }^{3}$, Haziqah Najwa ${ }^{4}$, Khairul Atiqah And ${ }^{5}$, Md Akmal Salihin ${ }^{6}$, Mohd.Shahril Ahmad ${ }^{7}$, Pengiran Norkhairiah ${ }^{8}$ 